\title{
ECG Replicates On-Treatment Indicator
}

National Cancer Institute

\section{Source}

National Cancer Institute. ECG Replicates On-Treatment Indicator. NCI Thesaurus. Code C119566.

An indication as to whether replicate ECGs for time points during the on-treatment portion of the study were included. 